\title{
Reproductive phenology of the American Bullfrog in subtropical Brazil: photoperiod as a main determinant of seasonal activity
}

\author{
CAMILA I. MEDEIROS ${ }^{1}$, CAMILA BOTH ${ }^{1}$, IGOR L. KAEFER ${ }^{2}$ and SONIA Z. CECHIN ${ }^{1}$ \\ ${ }^{1}$ Departamento de Biologia, Universidade Federal de Santa Maria, Avenida \\ Roraima, 1000, Camobi, 97105-900 Santa Maria, RS, Brasil \\ ${ }^{2}$ Departamento de Biologia, Universidade Federal do Amazonas, \\ Avenida General Rodrigo Octávio, 6200, Bairro Coroado, 69077-000 Manaus, AM, Brasil
}

Manuscript received on October 5, 2015; accepted for publication on March 1, 2016

\begin{abstract}
The North American bullfrog Lithobates catesbeianus continues to invade ecosystems worldwide, potentially causing population declines and even extinctions. Within its native distribution, bullfrogs show prolonged reproductive seasons and high fertility. However, data on breeding biology of bullfrogs ex-situ in invaded localities mainly comes from anecdotal reports. Understanding how invasive species are adjusting their life histories to new colonized environments is important for conservation purposes. Here we describe temporal and spatial abundance, calling activity, spawning and tadpole distribution of bullfrogs in southern Brazil. Eighteen samplings occurred during one year. The abundance of individuals was positively related to longer photoperiods and higher temperatures. Reproductive activity was also positively associated with longer photoperiods. Calling sites, spawning and tadpoles were associated with microhabitats presenting hydrophytes, which may provide shelter and thermal stability to bullfrogs. The reproductive seasonal activity of bullfrogs can be highly variable across its growing geographical range, but in subtropical Brazil it is associated with photoperiod, a highly predictable abiotic determinant. In our study area, bullfrogs presented a breeding season twice as long as that observed in some native localities. We suggest that management strategies directed to bullfrog populations must consider the habitat structures and seasonal regimes determined by each invaded environment.
\end{abstract}

Key words: breeding, invasive species, Lithobates catesbeianus, microhabitat, recruitment, spatial distribution.

\section{INTRODUCTION}

When a species is introduced into new environments it may be able to survive, establish populations and become invasive. Invasion success depends on biological attributes of the species (Kolar and

Correspondence to: Camila Ineu Medeiros

E-mail: camilamedeiros22@yahoo.com.br
Lodge 2001, Facon et al. 2006), presence of natural enemies (Settle and Wilson 1990, Keane and Crawley 2002) and availability of resources (Petren and Case 1996), among others. Once a species becomes invasive, its presence can have significant ecological impact and lead to the homogenization of entire ecosystems (Mack et al. 2000). The bullfrog Lithobates catesbeianus (Shaw 1802), one 
of the most successful invasive species of the world (IUCN 2003), has been introduced in more than 40 countries and four continents over the last century (Lever 2003). Its native region comprises southern Canada, the south-central and eastern United States and northern Mexico (Frost 1985, Frost 2015). At North American introduction sites of bullfrogs, the decline of various amphibian species was recorded (Bury and Luckenbach 1976, Hayes and Jennings 1986, Hecnar and M'Closkey 1997, Pearl et al. 2005). Experimental studies have shown that bullfrog tadpoles can reduce food resources for tadpoles of others species like Ranidae, Bufonidae, Hylidae and tiger salamander (Kupferberg 1997, Adams 2000, Boone et al. 2004). Bullfrogs also have the potential to affect native species in the acoustic niche (Both and Grant 2012). In addition, they can be a threat to native frogs through the dissemination of pathogens and diseases, such as chytridiomycosis (Berger et al. 1998, Daszak et al. 2004, Schoegel et al. 2010).

A series of studies on bullfrog biology conducted in Brazil indicate that this species has adapted to climatic conditions and can survive and reproduce in invaded areas (Boelter and Cechin 2007, Kaefer et al. 2007, Alves et al. 2008, Silva et al. 2009, Afonso et al. 2010, Leivas et al. 2012, Boelter et al. 2012). It has been suggested that bullfrogs might negatively affect various native species in Brazil, however there is a lack of evidence supporting such impacts (see Both et al. 2014).

Throughout its native distribution, L. catesbeianus is known to occupy mainly permanent water bodies, where it reproduces at high rates (Bury and Whelan 1984). The prolonged reproductive season is characterized by male calling activity periods (Emlen 1976, Ryan 1980, Bury and Whelan 1984) and by intense movement of females for partner selection (Wiewandt 1969, Howard 1978, Ryan 1980). Spawning may occur once or twice in a given reproductive cycle (Emlen 1977, Ryan 1980, Govindarajulu et al. 2006). However, few studies exist on the reproductive biology of bullfrogs in ex-situ populations in Brazil. In the state of Minas Gerais (southeastern Brazil), abundances of tadpoles are greater in the warmer months, coinciding with the period of male calling activity (Afonso et al. 2010). A similar pattern has been found for populations from Paraná (southern Brazil), where the species' reproductive activity is interrupted by low temperatures in autumn/winter (Conte and RossaFeres 2006, Leivas et al. 2012).

Breeding activity in anuran amphibians is more strongly influenced by abiotic than by biotic factors: environmental variables such as light, rainfall and temperature (Duellmann and Trueb 1994, Wells 2007). Additionally, photoperiod is increasingly known to influence the timing of reproduction in subtropical anuran assemblages. (Both et al. 2008, Canavero and Arim 2009), controlling events such as gametogenesis and anuran calling (Hatano et al. 2002, Kaefer et al. 2009). Thus, assessing the relation between reproductive activity and photoperiod presents an excellent opportunity to better understand the reproductive phenology of bullfrogs in the subtropics and evaluate its invasion success.

Gonadal analyses of L. catesbeianus in subtropical Brazil indicated that although mature males are found throughout the year, females produce gametes in advanced developmental stages only in spring and summer (Kaefer et al. 2007). However, in despite the fact that research on bullfrog invasion has been growing in the last 10 years (see Campos et al. 2014), little is known about the breeding phenology of this species for most of the invaded localities. The geographical location directly influences life history traits of invasive species, affecting its timing of reproduction, and other traits such as body size, sexual maturity and fecundity (Bury and Whelan 1984). Therefore, understanding how invasive species respond to environmental changes in invaded areas is one of the first steps to plan future studies and management strategies.

In this study, we characterized the reproductive phenology of bullfrogs in an invaded region in 
southern Brazil based on field observation records. We investigated which environmental descriptors could explain the abundance of males, females and juveniles of bullfrogs along the year. We described vocalization and spawning periods, as well as the temporal distribution of tadpoles, and characterized microhabitats where calling males, egg masses and tadpoles were found. Finally, we compared our data with phenological data reported from other invaded and native localities.

\section{MATERIALS AND METHODS}

\section{STUDY SITE}

We conducted the fieldwork in two permanent water bodies in the municipality of Faxinal do Soturno (29³4'008'S, 5325'386”O), state of Rio Grande do Sul, southern Brazil. The first water body (P1) has distinct vegetation zones with a large number of emergent or floating hydrophytes in shallow areas, while the water surface of deeper locations is free of hydrophytes (Brönmark and Hansson 2005). The second water body (P2) is characterized by dense and emergent vegetation across the entire water surface, and its banks as well are covered by vegetation. Both water bodies are mainly vegetated by plants of the families Cyperaceae (such as Eleocharis (R. Br. 1810)) and Poaceae (Rchb. 1828). In $\mathrm{P} 2$ we also recorded a significant presence of Araceae (Juss. 1789). The study site is located in an anthropogenically impacted area, near a tobacco plantation (Nicotiana sp.) and human habitations. The climate is classified as subtropical wet (Maluf 2000), with evenly distributed rainfall throughout the year (1500-1750 mm) and seasonality determined by temperature $\left(17-19{ }^{\circ} \mathrm{C}\right.$; Pereira et al. 1989).

FIELDWORK

Two observers conducted data collection in all sampling events during one year (from August 2010 to July 2011), totaling 18 field expeditions and 147 h 15 min of observations. Surveys occurred once a month in autumn and winter (August and September 2010; April to July 2011). We sampled fortnightly in the spring and summer (October to March 2010) because this is the period when both sexes display mature gonads in southern Brazil (Kaefer et al. 2007). This increased effort was employed with the intent to better characterize behavior and microhabitat use for the species.

We searched for spawning by visual inspection, while walking around the pond banks during the day. For each microhabitat with spawns present, we recorded depth, distance from the margin, and presence and type of structural vegetation. Vegetation types were categorized as 'emergent', 'submerse' and/or 'floating' hydrophytes. The collected spawns were preserved in $80 \%$ alcohol. Eggs were counted and a subsample of eggs (n $=10$ ) of each spawning was measured with the accuracy of $0.01 \mathrm{~mm}$ under a stereo-microscope. We sampled tadpoles at distinct microhabitats also during the day. We swept in diverse microhabitats (vegetated/non-vegetated, shallow/deep) of both ponds, from 0 to $2 \mathrm{~m}$ distance from the pond margins. In each microhabitat where tadpoles were present, we recorded the same parameters as for those with spawns. Tadpoles were preserved in $10 \%$ formalin solution (Permit Proc 23009-1) and staged in the laboratory according to Gosner's stages of development (Gosner 1960). We deposited voucher specimens in the Herpetological Collection at Universidade Federal de Santa Maria (ZUFSM). The number of calling males was assessed every hour from 6 p.m. until vocalization consistently decreased (around 5 a.m.). We dedicated a minimum of three hours of nocturnal observations even when no individuals or signs of reproductive activity were found. We characterized the microhabitat of calling males using the parameters depth, distance from bank and presence and type of vegetation. We also conducted sporadic observations of reproductive activity throughout the day. Two hours after sunset, we conducted visual surveys to count all individuals in the ponds. The located individuals 
were classified as males, females or juveniles. Males were considered mature when calling activity was observed, or when morphological sexual characters were present, such as the yellow ventral coloration, and large dark eardrum. Animals without these characters and visually larger when compared with mature males were considered females (Howard 1981). Immature small sized individuals were considered juveniles. In the field, it is easy to visually recognize adults, which are large sized and dimorphic, and juveniles, which are small sized. Due to difficulties in classifying individuals between those life stages, they were included in a fourth class ('undetermined'). Behavioral observations were conducted focally (Martin and Bateson 1986), with occasional use of flashlights, at a distance of 2-3 m.

\section{ENVIRONMENTAL DESCRIPTORS}

We estimated pond area monthly using measuring tape. We measured pond depth at $1 \mathrm{~m}$ distance from the pond banks ( $\mathrm{n}=8$, for each pond) in all sample events. We recorded the temperature and relative air humidity with a digital hygrometer at the beginning of sampling, and every hour from 6 p.m. until a significant reduction in calling activity. For the analysis described below we used maximum, minimum and mean temperature per collection event. Precipitation data were obtained from http://www.inmet.gov.br, Instituto Nacional de Meteorologia (INMET 2012). These data are recorded at the automatic station of the municipality Santa Maria, $30.56 \mathrm{~km}$ from the study site. As precipitation descriptors, we used the amount of rainfall on the sampling day, five days previous to sampling, and the rainfall accumulated in the last month. Photoperiod data were obtained from http:// euler.on.br/ephemeris/index.php, Observatório Nacional Brasileiro (2012).

STATISTICAL ANALYSIS

The relationship between environmental descriptors and total abundance of individuals observed in each sampling event was tested using linear mixed models. In the following analyses, we used the maximum abundances observed in a single event to represent months with multiple surveys. We used a backward-stepwise procedure to eliminate non-significant variables (Zar 1999). We also used mixed-linear models (stepwise procedure) to relate male, female and juvenile abundance and male calling activity to the environmental descriptors. In addition to the environmental variables described above, we used the maximum number of calling males as a possible predictor of female abundance. All analyses were conducted in the $\mathrm{R}$ environment (R Development Core Team 2012).

\section{BIBLIOGRAPHIC REVIEW}

We searched scientific papers and dissertations in order to obtain data on the reproductive phenology of $L$. catesbeianus in native and invaded areas. The search was conducted in the following databases: Web of Science, SciELO.ORG., Science, Scopus, Biological Abstracts, ScienceDirect, Wiley Online Library, Nature, Oxford Journals and Annual Reviews. We conducted searches using the popular name "Bullfrog" and the previous and current scientific names for the species ('Rana catesbeiana' and 'Lithobates catesbeianus', respectively) in combination with the terms 'breeding', 'reproduction', 'reproductive biology', 'call', 'eggs', 'clutch', 'spawn' and 'tadpoles'. Based on the results of this review, we compiled a database with information on the reproductive biology and life cycle of the species, for both its native and invaded ranges.

\section{RESULTS}

ABUndANCE AND REPRODUCTIVE PHENOLOGY

The abundance of $L$. catesbeianus observed in the two ponds ranged from three individuals in April to 103 individuals in December (Figure 1). Juveniles were more abundant and were observed on all surveys. Highest abundances were observed in 
November and December $(n=47, n=40$; respectively). On average, $22.55(\mathrm{SD}=17.43)$ individuals per sampling could not be classified to one of the three categories. Calling males were observed from August to April. Sparse vocalizations were recorded during the day, starting at $16 \mathrm{~h}$, and calls became frequent after $18 \mathrm{~h}$. During the spring months, a higher number of calling males (4-6) was observed between 17 and $23 \mathrm{~h}$, while during the summer months most calling males were active between 2 and 5 h. (Figure 2). Spawnings were recorded

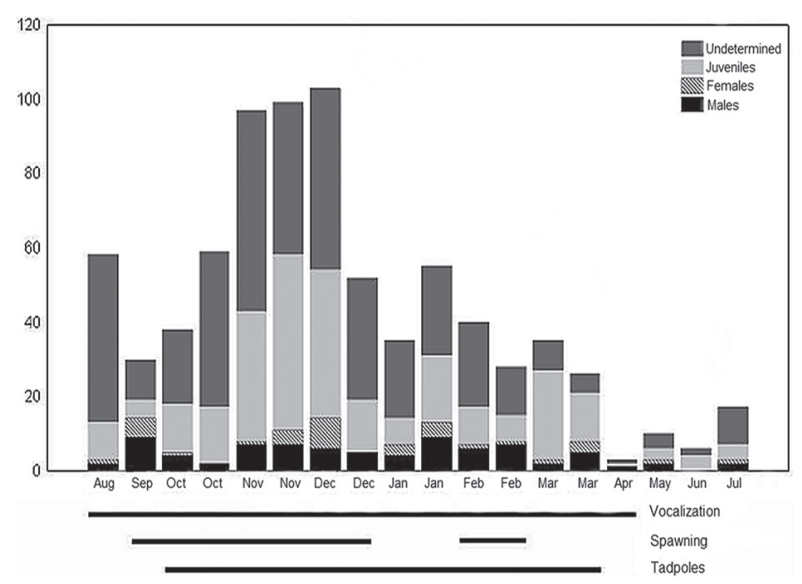

Figure 1 - Abundance of Lithobates catesbeianus in two permanent water bodies in Faxinal do Soturno, southern Brazil, between August 2010 and July 2011. Lines represent the occurrence of vocalizations, spawns and tadpoles throughout the year.

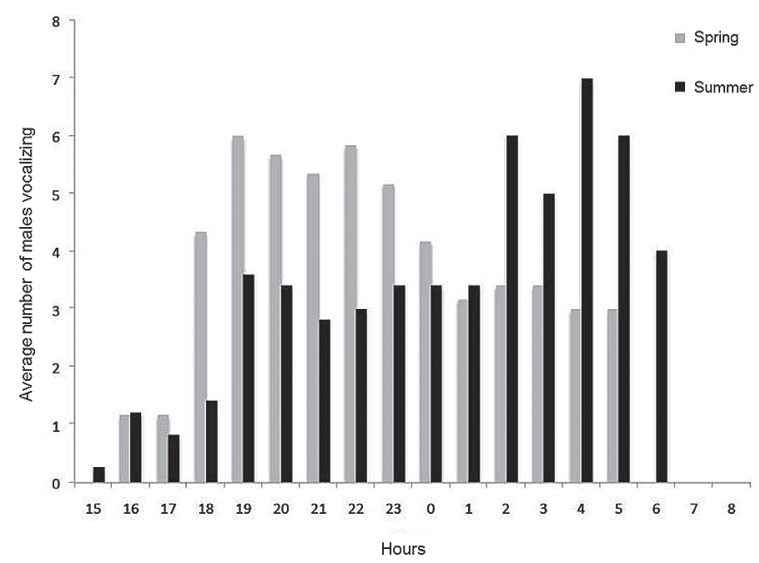

Figure 2 - Daily cycle of calling activity of Lithobates catesbeianus from southern Brazil in spring and summer between August 2010 and July 2011. from September to February $(n=5)$. The number of eggs counted in three spawnings ranged from 3.405 to $9.314(\overline{\mathrm{X}}=6.840, \mathrm{SD}=3069.3)$. Egg size ranged from 5.6 to $6.9 \mathrm{~mm}(\mathrm{n}=30, \overline{\mathrm{X}}=6.2, \mathrm{SD}=$ 0.48). Tadpoles were found throughout the spring and summer months, from October to March. In spring, we found tadpoles between stages 22 and 30 (Gosner's stages), with one exception at stage 38. In summer, the collected tadpoles were between stages 25 and 40. In February, we observed a metamorph at stage 45 . The total abundance of $L$. catesbeianus over the study period was explained by photoperiod and minimum temperature $\left(\mathrm{R}^{2}=\right.$ $\left.0.58 ; \mathrm{F}_{3,15}=12.93 ; \mathrm{p}<0.05\right)$. The number of observed individuals increased with longer photoperiods, and slightly decreased when minimum temperatures were higher (Figure 3). Photoperiod was the only predictor that explained both the monthly abundance of males $\left(\mathrm{R}^{2}=0.39 ; \mathrm{F}_{2,16}=12.08 ; \mathrm{p}<\right.$ $0.05)$ and the number of calling males $\left(\mathrm{R}^{2}=0.36\right.$; $\left.\mathrm{F}_{2,16}=10.80 ; \mathrm{p}<0.05\right)$. Female monthly abundance showed a positive correlation with male monthly abundance $(\mathrm{r}=0.6 ; \mathrm{p}<0.05)$. The juvenile monthly abundance was also unrelated to any of the environmental predictors.

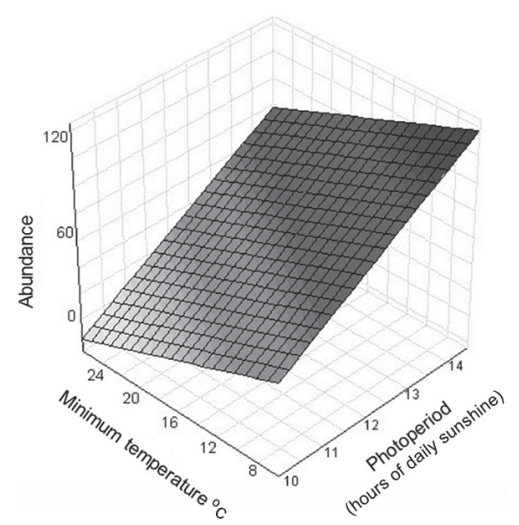

Figure 3 - Relationship between total abundance of Lithobates catesbeianus and the environmental variables of minimum temperature and photoperiod throughout 18 months in southern Brazil. 
Microhabitats of CALLing MALEs, EgG MASSES AND TADPOLES

The distance of calling sites $(\mathrm{n}=15)$ from pond banks varied from 0.4 to $3.7 \mathrm{~m}(\overline{\mathrm{X}}=6.02 \mathrm{~m}, \mathrm{SD}=$ $4.30)$ with depths varying from 0.14 to $0.85 \mathrm{~m}(\overline{\mathrm{X}}=$ $0.43 \mathrm{~m}, \mathrm{SD}=0.22$ ). All calling sites contained hydrophytes, with most sites combining two or more structural types of hydrophytes $(60 \%, n=9)$. There was a predominance of emergent hydrophytes, which were present at all sampled sites. Floating hydrophytes were recorded in $53.33 \%$ and submerged hydrophytes in $33.33 \%$ of the sites. Egg masses $(\mathrm{n}=5)$ were observed at distances between 0.71 and $2.70 \mathrm{~m}$ from pond banks $(\overline{\mathrm{X}}=1.76 \mathrm{~m}$, $\mathrm{SD}=0.86)$, with microhabitat depth ranging from 0.17 to $0.76 \mathrm{~m}(\overline{\mathrm{X}}=0.45 \mathrm{~m}, \mathrm{SD}=0.24)$. All egg masses were deposited in vegetated microhabitats, predominantly covered by Poaceae and Cyperaceae plants. Only one of the five egg masses was found in a microhabitat with submerged hydrophytes only. Tadpoles were found in microhabitats $(\mathrm{n}=$ 41 ) at distances varying between 0.58 and $11.24 \mathrm{~m}$ to pond banks $(\overline{\mathrm{X}}=2.20 \mathrm{~m}, \mathrm{SD}=1.82)$, and depths from 0.9 to $0.59 \mathrm{~m}(\overline{\mathrm{X}}=0.22 \mathrm{~m}, \mathrm{SD}=0.10)$. We found 442 tadpoles in the 41 microhabitats sampled, only one of which lacked hydrophytes.

\section{STUDIES ANALYZED}

We found 23 studies conducted in eight countries in North America, South America, Europe and Asia that addressed the reproductive phenology of $L$. catesbeianus (Table I). The calling activity coincided with the hottest months at all locations. In the Northern Hemisphere, vocalizations occurred from April to July (four months), while in the Southern Hemisphere they occurred from September to April (eight months). Information about spawning was available only for the Northern Hemisphere, where egg masses can be found between April and July. The spawn sizes varied from 7.296 to 47.870 eggs (Table I). In Brazil, tadpoles can be found through- out the year in several stages, and there is no data on the period of metamorphosis. In Canada and the United States, metamorphosis occurs between July and October.

\section{DISCUSSION}

Considering the widespread occurrence of $L$. catesbeianus in Brazil, few studies on the natural history of this invasive species were conducted, especially studies reporting field-acquired data. This study is the first to detail the long reproductive period and reporting data such as microhabitat preferences of the species in southern Brazil. Our data support a close relationship between reproductive phenology and photoperiod, which seems to be the main predictor of reproductive activity of native species in the region (Both et al. 2008, Kaefer et al. 2009).

Photoperiod was the best predictor of calling activity for anuran assemblages in subtropical regions (Both et al. 2008, Kaefer et al. 2009, Canavero and Arim 2009). Bambozzi et al. (2004) demonstrated that this variable is positively related to weight gain and metamorphosis rates of $L$. catesbeianus tadpoles. In addition, Figueiredo et al. (2001) showed that photoperiod is responsible for reproductive organ development in this species in captivity. The influence of seasonal change on the behavior and physiology of organisms is a widespread phenomenon, and photoperiod is the most reliable predictor of these changes (Vaze and Sharma 2013). The response to photoperiod is considered one of the most important adaptations to seasonal variation, with direct implications on survival and reproductive success (Vaze and Sharma 2013). The distinct behavioral patterns of male bullfrogs between spring and summer months may be related to the differences in photoperiod and temperature between these two periods. Thus, longer days in the summer could influence males to start calling and to reach their peak activity later in the night than in spring nights. 


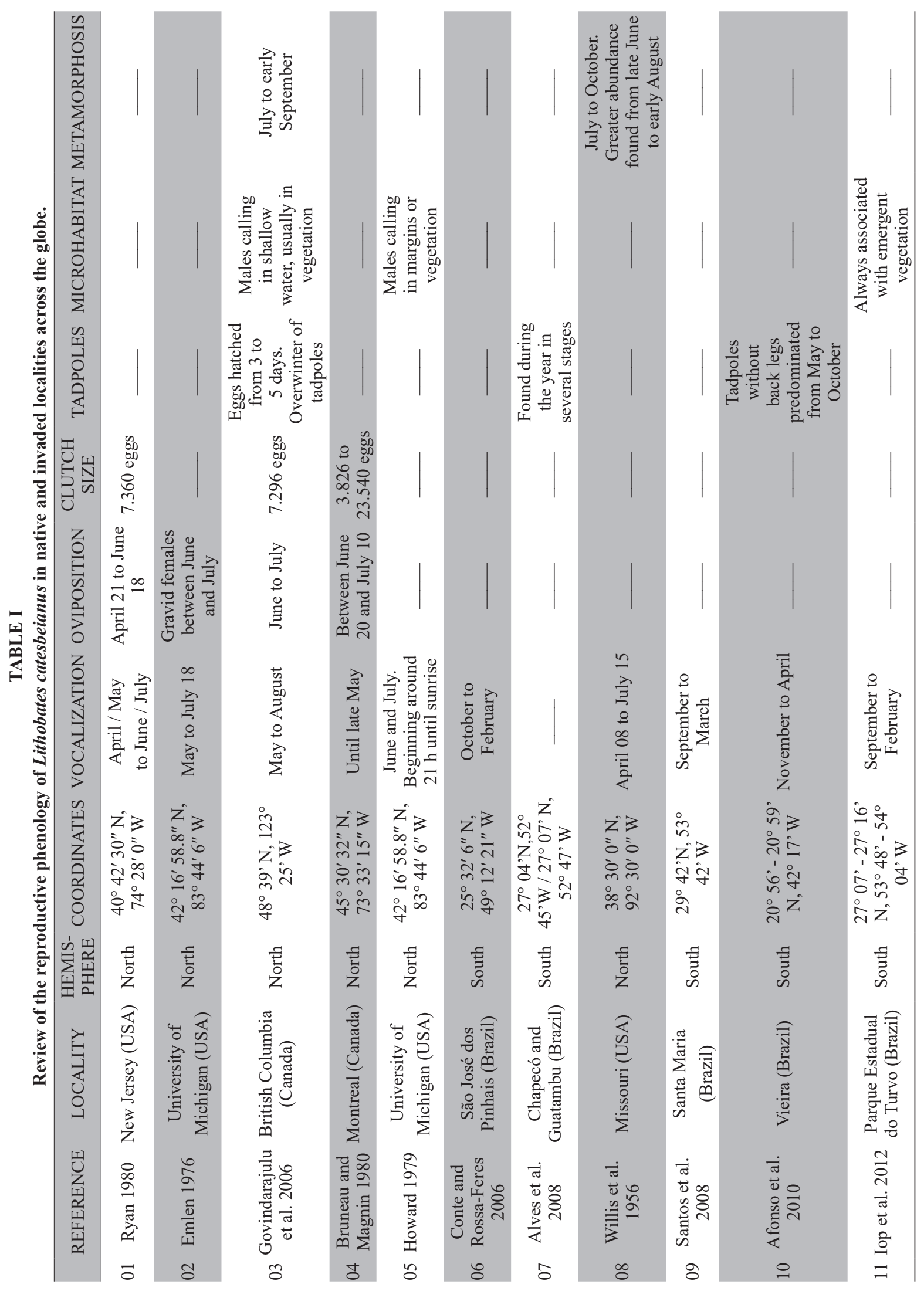




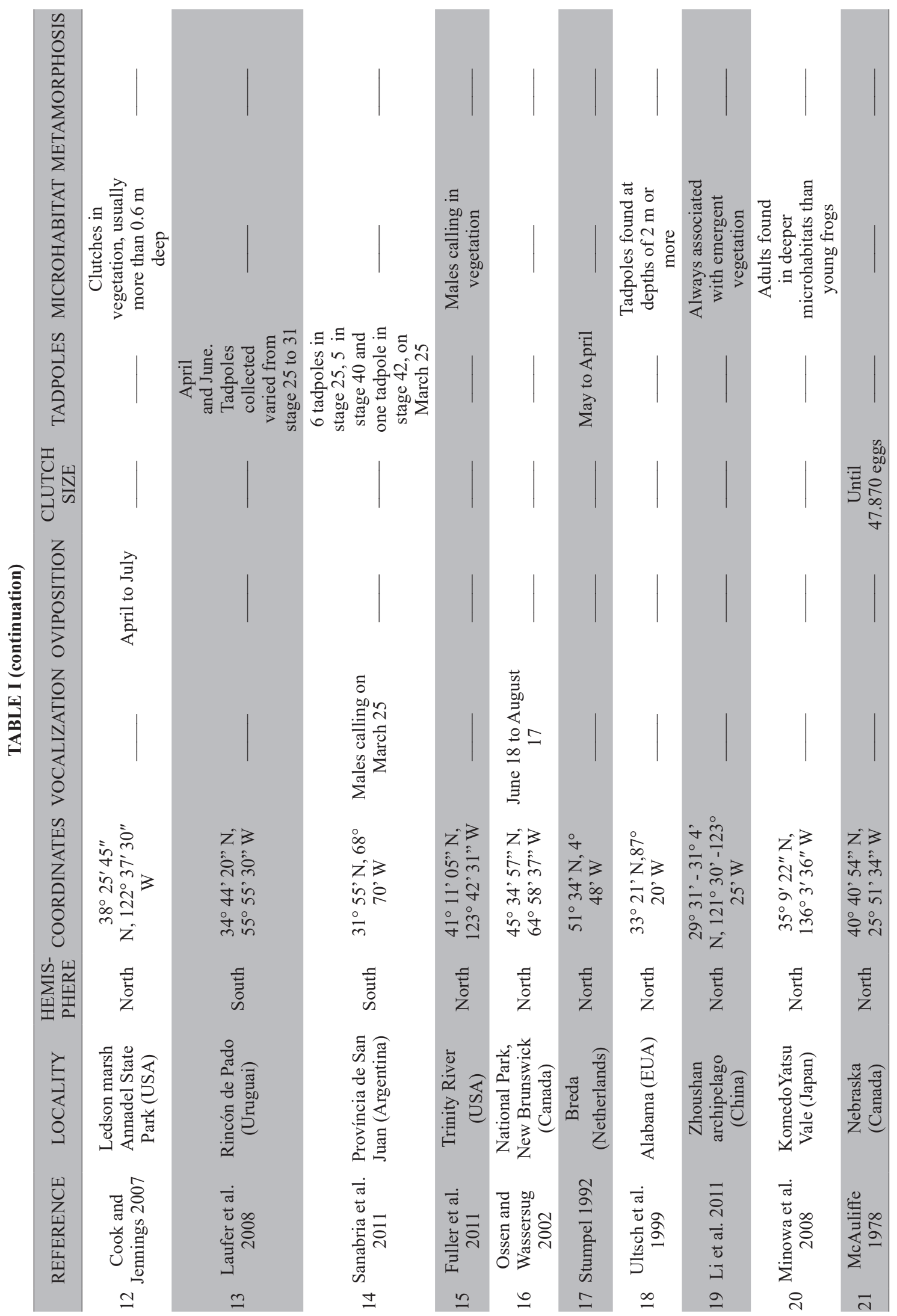


We did not record reproductive activities or tadpoles during autumn and winter months. Adults, when observed in the colder months, remained in the water. These periods in North America are referred to torpor (Willis et al. 1956, Howard 1981, Govindarajulu 2006). We observed bullfrogs in this state of low activity only between late May and early July, but more observations are required for its classification as torpor. Our tadpole sampling was restricted to pond banks, reaching microhabitats only up to $2 \mathrm{~m}$ distance from the banks, and we were not able to detect larger larvae possibly occurring in deeper microhabitats. According to Minowa et al. (2008), tadpoles of L catesbeianus hibernate at the bottom of water bodies during the colder months. Due to their long larval stage, which usually exceeds one year (Bury and Whelan 1984), it is probable that tadpoles are present in the pond throughout the year. Besides, we also found tadpoles at advanced developmental stages in spring at the onset of vocalizations, which means that they most likely had overwintered.

We generally found adults in deeper microhabitats than juveniles, a pattern also reported by Lillywhite (1970), Graves and Anderson (1987) and Minowa et al. (2008) in the Northern Hemisphere. According to Graves and Anderson (1987), this pattern may be related to adults preferring deeper water to hide from predators present close to the pond margins. However, in Brazil there are no records of predators of adult bullfrogs, while predators of juveniles exist (Silva and Filho 2009, Medeiros et al. 2012). However, the microhabitat segregation could also be related to the avoidance of cannibalism, which is common in this species (Boelter et al. 2012). Juveniles were observed to avoid areas close to adult males in both ponds (Medeiros, C. pers. obs.). Juveniles of another invasive anuran, Rhinella marina, are also known to avoid cannibalistic adults. In this case, juveniles try to segregate from adults by changing temporal activity: their activity is diurnal while adults are nocturnal
(Pizzatto et al. 2008). Nonetheless, the difference in microhabitat use between adults and juveniles may be related to thermoregulation, which can be achieved by changes in body posture to use warmer pond water as a heat source (Lillywhite 1970).

Males of L. catesbeianus are territorial, defending sites where hydrophytes dominate. In January 2011 we observed an event of physical combat between two males at daytime, associated with territoriality. We were also able to observe, at multiple times, males engaged in other antagonistic interactions denominated by Howard (1978) as 'Threat or Display'. Males raise the bodies and display their yellow throat region, and occasionally vocalize. The territoriality exerts an important selection pressure because it provides an advantage to the males that occupy the best breeding sites (Ryan 1980). In our study we found that calling and oviposition sites were often identical, which confirms the above assertion. Nevertheless, males were often observed calling near egg masses.

Tadpoles and egg masses of $L$. catesbeianus were present in vegetated microhabitats close to pond banks. In addition to providing shelter, refuge and food source, the presence of hydrophytes in aquatic systems plays an important role in stabilizing environmental conditions by maintaining thermal stability required by several species (Nessimian and De Lima 1997). Furthermore, hydrophytes retain organic particles that can be used by other organisms (Nessimian and De Lima 1997). It is also possible that calling from vegetated sites saves energy, since plants can support males in staying above the water surface for vocalization activity.

According to our results and all analyzed studies, the reproduction of $L$. catesbeianus is restricted to the warmer months of the year. It is assumed that in the Northern Hemisphere, in addition to temperature, precipitation is an environmental cue for the onset of reproduction (Ryan 1980). The effect of rainfall on bullfrog reproductive activity was not recorded in our study, probably because precipitation is evenly distributed throughout the year in 
subtropical Brazil. According to Figueiredo et al. (2001), body fat increases with temperature, indicating the preparation of animals for energy expenditure involved in reproduction. As observed here, this preparation is mainly associated with photoperiod, since seasons with higher temperatures also have the longest photoperiods. With small differences between hemispheres, the breeding season of $L$. catesbeianus is restricted to periods of higher temperatures.

The importance of natural history investigations has been historically underestimated, although the increasing recognition that they constitute the first step to hypothesis-driven, applied studies (Vitt 2013). Invasion management can benefit from crucial information about the relationship of alien species and newly colonized environments, including distribution of individuals over space and time. When suggesting habitat modification as an effective strategy for long-term management (Graves and Anderson 1987, Adams et al. 2003), the microspatial and seasonal preferences of invasive species such as those described here must be taken into account. Our results evidenced the remarkable phenotypic plasticity of bullfrogs, where reproductive period and spawn size largely varied among localities. We suggest that management strategies directed to bullfrog populations must be idiosyncratic by considering the different habitat structures and seasonal regimes determined by each invaded environment across the globe.

\section{ACKNOWLEDGMENTS}

We are grateful to Mr. Alceu Menegheti, who kindly allowed access to the study sites, and to Samanta Iop for providing data. We also thank Abner Pontelli Perez, Wagner Moro, Vilson Molinaro (in memoriam), Tailise Dias, Bruno Madallozo, Miguel Machado, George Polidoro, Juliana Costa, Mariane Bolsholn, Lana Carla Vieira, Éder Rodrigues and Carlos Silveira Cézar for their help in field and/or laboratory activities. We also thank Instituto Chico Mendes de Conservação da Biodiversidade (ICMBio) for the license to conduct this research (Proc 23009-1). C.M. received a Programa Institucional de Bolsas de Iniciação Científica (PIBIC) CNPq scholarship, and S.C. received a research fellowship from Conselho Nacional de Desenvolvimento Científico de Tecnológico (CNPq, 304929/2012-3).

\section{RESUMO}

A rã-touro americana continua invadindo ecossistemas em todo o mundo, causando declínios e extinções nas populações. Em sua distribuição nativa, a espécie apresenta estação reprodutiva prolongada e grande fertilidade. Contudo, dados sobre a fenologia reprodutiva da espécie ex-situ em localidades invadidas provêm principalmente de relatos anedóticos. Compreender como espécies invasoras ajustam sua história de vida para colonizar novos ambientes é importante para fins de conservação. Aqui, nós descrevemos a abundância temporal e espacial, atividade de vocalização, e a distribuição de desovas e girinos da rã-touro no sul do Brasil. Dezoito amostragens ocorreram durante um ano. A abundância de indivíduos foi positivamente correlacionada com longos fotoperíodos e altas temperaturas. A atividade reprodutiva também foi positivamente associada a longos fotoperíodos. Sítios de vocalização, desovas e girinos estiveram sempre associados à microhabitats com a presença de hidrófitas, que podem prover abrigo e estabilidade térmica à espécie. A atividade reprodutiva sazonal da rã-touro pode ser altamente variável em toda a sua crescente distribuição geográfica, mas no Brasil subtropical, a reprodução está associada com o comprimento do dia, um determinante biótico altamente previsível. Em nossa área de estudo, a rã-touro se reproduz pelo dobro do tempo observado em algumas localidades nativas. Nós sugerimos que estratégias de manejo voltadas para populações da espécie devem considerar as estruturas do habitat e regimes sazonais determinados por cada ambiente invadido.

Palavras-chave: reprodução, espécies invasoras, Lithobates catesbeianus, Microhabitat, recrutamento, distribuição espacial. 


\section{REFERENCES}

ADAMS MJ. 2000. Pond permanence and the effects of exotic vertebrates on anurans. Ecol Appl 10: 559-568.

ADAMS MJ, PEARL CA AND BURY RB. 2003. Indirect facilitation of an anuran invasion by non-native fishes. Ecol Lett 6: 343-351.

Afonso LG, Carvalho R, SAntos FM, Coelho ACB AND MAGAlHÃES ALB. 2010. Reprodução da exótica rã-touro Lithobates catesbeianus (Shaw, 1802) (Amphibia, Anura, Ranidae) em riachos de Mata Atlântica no estado de Minas Gerais, Brasil. Biotemas 23: 85-91.

ALVES FC, BRANDO A, LUCAS EM AND FORTES VB. 2008. Ocorrência da espécie exótica Lithobates catesbeianus (rãtouro) em ambientes naturais nos municípios de Chapecó e Guatambu, Santa Catarina, Brasil. Acta Amb Catar 5: $35-42$.

BAmBOzZI AC, FiLHO JTS, THOMAZ LA AND OSHIRO LMY.2004. Efeito do fotoperíodo sobre o desenvolvimento de girinos de rã-touro (Rana catesbeiana Shaw, 1802). R Bras Zootec 33: 1-7.

BERGER L ET AL. 1998. Chytridiomycosis causes amphibian mortality associated with population declines in the rain forests of Australia and Central America. Proc Natl Acad Sci 95: 9031-9036.

BOELTER RA AND CECHIN SZ. 2007. Impact of the bullfrog diet (Lithobates catesbeianus, Anura, Ranidae) on native fauna: case study from the region of Agudo-RS-Brazil. Nat Conserv 5: 115-123.

Boelter RA, KAEFER IL, BOTH C AND CECHIN SZ. 2012. Invasive bullfrogs as predators in a Neotropical assemblage: What frog species do they eat? Anim Biol 62: 397408.

Boone MD, Little EE, Semlitsch RD And Fox SF. 2004. Overwintered Bullfrog Tadpoles Negatively Affect Salamanders and Anurans in Native Amphibian Communities. Copeia 3: 683-690.

Both C AND GRANT T. 2012. Biological invasions and the acoustic niche: the effect of bullfrog calls on the acoustic signals of white-banded tree frogs. Biol Lett 8: 714-716.

Both C, Kaefer IL, SANtos TG AND CECHIN STZ. 2008. An austral anuran assemblage in the Neotropics: seasonal occurrence correlated with photoperiod. J Nat Hist 42: 205-222.

Both C, MADALOZZO B, LINGNAU R AND GRANT T. 2014. Amphibian richness patterns in Atlantic Forest areas invaded by American bullfrogs. Austral Ecol 39: 864-874.

BRÖNMARK C AND HANSSON LA. 2005. The biology of lakes and ponds. New York: Oxford University Press, 285 p.

BRUNEAU M AND MAGNIN E. 1980. Croissance, nutrition et reproduction des ouaouarons Rana catesbeiana Shaw (Amphibia Anura) des Laurentides au nord de Montréal. Can J Zool 58: 175-183.
BURY RB AND LUCKENBACH RA. 1976. Introduced amphibians and reptiles in California. Biol Conserv 10: 1-14.

BURY RB AND WHELAN JA. 1984. Ecology and Management of the Bullfrog. U.S. Fish and Wildlife Service. Resource Publication 155, Washington, DC, 23 p.

CAMPOS FS, BRITO D AND SOLÉ M. 2014. Diversity patterns, research trends and mismatches of the investigative efforts to amphibian conservation in Brazil. An Acad Bras Cienc 86: 1873-1886.

CANAVERO A AND ARIM M. 2009. Clues supporting photoperiod as the main determinant of seasonal variation in amphibian activity. J Nat Hist 43: 2975-2984.

CONTE CE AND RossA-FERES DC. 2006. Diversidade e ocorrência temporal da anurofauna (Amphibia, Anura) em São José dos Pinhais, Paraná, Brasil. Rev Bras Zool 23: 162-175.

COOK DG AND JENNINGS MR. 2007. Microhabitat use of the california red-legged frog and introduced bullfrog in a seasonal marsh. Herpetologica 63: 430-440.

DASZAK P, Strieby A, CUNNINGHAM AA, LONGCORE JE, BROWN CC AND PORTER D. 2004. Experimental evidence that the bullfrog (Rana catesbeiana) is a potential carrier of chytridiomycosis, an emerging fungal disease of amphibians. Herpetol J London 14: 201-207.

DUELLMAN WE AND TRUEB L. 1994. Biology of amphibians. Baltimore: Johns Hopkins University Press, 670 p.

EMLEN ST. 1976. Lek organization and mating strategies in the bullfrog. Behav Ecol Sociobiol 1: 283-313.

EMLEN ST. 1977. "Double clutching" and its possible significance in the bullfrog. Copeia 4: 749-751.

FACON B, GENTON BJ, SHYKOFF J, JARne P, Estoup A AND DAVID P. 2006. General ecoevolutionary framework for understanding bioinvasions. Trends Ecol Evol 21: 130135 .

FIGUEIREDO MRC, LIMA SL, AGOSTINHO CA AND BAÊTA FC. 2001. Efeito da Temperatura e do Fotoperíodo sobre o Desenvolvimento do Aparelho Reprodutor de Rã-touro (Rana catesbeiana Shaw, 1802). R Bras Zootec 30: 916-923.

FROST DR. 1985. Amphibian species of the world: A taxonomic and geographical reference. Lawrence: Allen Press, $732 \mathrm{p}$.

FROST DR. 2015. Amphibian Species of the World: An Online Reference. Version 6.0. Electronic Database accessible at http://research.amnh.org/herpetology/amphibia/index. html. American Museum of Natural History, New York, USA.

Fuller TE, Pope KL, AShton DT AND Welsh JR HH. 2011. Linking the Distribution of an Invasive Amphibian (Rana catesbeiana) to Habitat Conditions in a Managed River System in Northern California. Restoration Ecol 19: 204-213.

GOSNER KL. 1960. A Simplified Table for Staging Anuran Embryos and Larvae with Notes on Identification. Herpetologica 16: 183-190. 
GOVIndARAJUlu P, PRICE WMS AND ANHOLT BR. 2006. Introduced Bullfrogs (Rana catesbeiana) in Western Canada: Has Their Ecology Diverged? J Herpetol 40: 249260.

GRAVES BM AND ANDERSON SH. 1987. Habitat suitability index models: bullfrog. US Fish and Wildlife Service. Biological Report 82, Washington, DC, 22 p.

HATANO FH, ROCHA CFD AND VAN SLUYS M. 2002. Environmental factors affecting calling activity of a tropical diurnal frog (Hylodes phyllodes: Leptodactylidae). J Herpetol 36: 314-318.

HAYES MP AND JENNINGS MR. 1986. Decline of ranid frog species in western North America: are Bullfrogs (Rana catesbeiana) responsible? J Herpetol 20: 490-509.

HeCNAR SJ AND M'Closkey RT. 1997. Changes in the composition of a ranid frog community following Bullfrog extinction. Am Midl Nat 137: 145-150.

HOWARD RD. 1978. The evolution of mating strategies in bullfrogs, Rana catesbeiana. Evol 32: 850-871.

HOWARD RD. 1979. The influence of male-defended oviposition sites on mortality in bullfrogs. Ecol 59: 789-798.

HowARD RD. 1981. Sexual Dimorphism in Bullfrogs. Ecol 62: 303-310.

INMET - Instituto NACIONAL DE MEteorologia. 2012. Available from: http://www.inmet.gov.br.

IOP S, CALDART VM, SANTOS TGS AND CECHIN SZ. 2012. What is the Role of Heterogeneity and Spatial Autocorrelation of Ponds in the Organization of Frog Communities in Southern Brazil? Zool Stud 51: 1094-1104.

IUCN - INTERNATIONAL UNION FOR CONSERVATION OF NATURE. 2003. 100 of the world's worst invasive alien species. Invasive Species Specialist Grup, Aukcland, New Zeland. Available from: http://www.issg.org/pdf/ publications/worst_100/english_100_worst.pdf.

KAEFER IL, BOELTER RA AND CECHIN SZ. 2007. Reproductive biology of the invasive bullfrog Lithobates catesbeianus in southern Brazil. Ann Zool Fenn 44: 435-444.

KAEFER IL, Both C AND CECHIN SZ. 2009. Breeding biology of the rapids frog Limnomedusa macroglossa (Anura: Cycloramphidae) in southern Brazil. J Nat Hist 43: 1195-1206.

KEANE RM AND CRAWLEY MJ. 2002. Exotic plant invasions and the enemy release hypothesis. Trends Ecol Evol 17: 167-170.

Kolar CS AND LodGE DM. 2001. Progress in invasion biology: predicting invaders. Trends Ecol Evol 16: 199204.

KUPFERBERG SJ. 1997. Bullfrog (Rana catesbeiana) invasion of a California River: the role of larval competition. Ecol 78: 1736-1751.

LAUfer G, CANAVERo A, NuÑEZ D AND MANEYRo R. 2008. Bullfrog (Lithobates catesbeianus) invasion in Uruguay. Biol Invasions 10: 1183-1189.
LEIVAS PT, MOURA MO AND FÁVARO LF. 2012. The Reproductive Biology of the Invasive Lithobates catesbeianus (Amphibia: Anura). J Herpetol 46: 153-161.

LEVER C. 2003. Naturalized amphibians and reptiles of the world. New York: Oxford University Press, 344 p.

LI Y, KE Z, WANG Y AND BLACKBURN TM. 2011. Frog community responses to recent American bullfrog invasions. Curr Zool 57: 83-92.

LILLYWHITE HB. 1970. Behavioural temperature regulation in the bullfrog, Rana catesbeiana. Copeia 158-168.

MACK RN, SimberlofF D, LONSDALE WM, EVANS H, ClOUt MN AND BAZZAZZ F. 2000. Biotic invasions: causes, epidemiology, global consequences and control. Issues Ecol 5: 1-20.

MALUF JRT. 2000. Nova classificação climática do Estado do Rio Grande do Sul. RBA Santa Maria 8(1): 141-150.

MARTIN P AND BATESON P. 1986. Measuring behaviour: an introductory guide. Cambridge: Cambridge University Press, $200 \mathrm{p}$.

MCAULIFFE JR. 1978. Biological survey and management of sport-hunted bullfrog populations in Nebraska. Lincoln: Nebraska Game Parks Com, 78 p.

Medeiros CI, Both C AND CECHIN SZ. 2012. Lithobates catesbeianus (Amphibia, Anura, Ranidae): predação por Erythrolamprus semiaureus. Herp Bras 1: 109-111.

MinOWA S, SENGA Y AND MIYASHITA T. 2008. Microhabitat Selection of the Introduced Bullfrogs (Rana catesbeiana) in Paddy Fields in Eastern Japan. Curr Herpetol 27: 55-59.

NeSSimian JL AND DE LIMA IHAG. 1997. Colonização de três espécies de macrófitas por macroinvertebrados aquáticos em um brejo no litoral do estado do Rio de Janeiro. Acta Limnol Bras 9: 149-163.

OBSERVATÓRIO NACIONAL BRASILEIRO. 2012. Available from: http://www.euler.on.br.

OSSEN KL AND WASSERSUG RJ. 2002. Environmental factors influencing calling in sympatric anurans. Oecol 133: 616-625.

PEARL CA, HAYES MP, HAYCOCK R, ENGLER JD AND BOWERMAN J. 2005. Observations of Interspecific Amplexus Between Western North American Ranid Frogs and the Introduced American Bullfrog (Rana catesbeiana) and a Hypothesis Concerning Breeding Interference. Am Midl Nat 154: 126-134.

PEREIRA PRB, NETTO LRG, BORIN CJA AND SARTORI MGB. 1989. Contribuição à geografia física do município de Santa Maria: unidades de paisagem. Geograf Ensino Pesquisa 3: 37-68.

PETREN K AND CASE TJ. 1996. An experimental demonstration of exploitation competition in an ongoing invasion. Ecol 77: 118-132.

PIZZATTO L, CHILD T AND SHINE R. 2008. Why be diurnal? Shifts in activity time enable young cane toads to evade cannibalistic conspecifics. Behav Ecol 19: 990-997. 
R DeVElopment Core TEAM. 2012. R: a language and environment for statistical computing. R Foundation for Statistical Computing, Vienna, Austria.

RYAN MJ. 1980. The reproductive behavior of the bullfrog (Rana catesbeiana). Copeia 1: 108-114.

SANABRIA E, RIPOLL Y, JORDAN M, QUIROGA L, ARIZA M, GUILLEMAIN M, PÉREZ M AND CHÁVEZ H. 2011. A new record for American Bullfrog (Lithobates catesbeianus) in San Juan, Argentina. Rev Mex de Biodivers 82: 311-313.

SAntos TG, KopP K, SPIES MR AND CECHIN SZ. 2008. Distribuição temporal e espacial de anuros em área de Pampa, Santa Maria, RS. Iheringia, Sér Zool 98: 244-253.

SCHOEGEL LM, DASZAK P, CUNNINGHAM AA, SPEARE R AND HILL B. 2010. Two amphibian diseases, chytridiomycosis and ranaviral disease, are now globally notifiable to the World Organization for Animal Health (OIE): An assessment. Dis Aquat Org 92: 101-108.

SETTLE WH AND WiLson LT. 1990. Invasion by the Variegated Leafhopper and Biotic Interactions: Parasitism, Competition, and Apparent Competition. Ecol 71: 1461-1470.

SILVA ET AND FILHO OPR. 2009. Predation on juveniles of the invasive American bullfrog Lithobates catesbeianus (Anura, Ranidae) by native frog and snake species in South-eastern Brazil. Herpetol Notes 2: 215-218.

Silva ET, REIS EP, FEIO RE AND FILHO OPR. 2009. Diet of the invasive frog Lithobates catesbeianus (Shaw, 1802)
(Anura: ranidae) in Viçosa, Estado de Minas Gerais, Brazil. South Am J Herpetol 4: 286-294.

STUMPEL AHP. 1992. Successful reproduction of introduced bullfrogs Rana catesbeiana in northwestern Europe: a potential threat to indigenous amphibians. Biol Conserv 60: 61-62.

Ultsch GR, REESE SA, NIE M, CRIM JD, SMITH WH AND LEBERTE CM. 1999. Influences of temperature and oxygen upon habitat selection by bullfrog tadpoles and three species of freshwater fishes in two Alabama strip mine ponds. Hydrobiologia 416: 149-162.

VAZE KM AND SHARMA VK. 2013. On the Adaptive Significance of Circadian Clocks for Their Owners. Chronobiol Int 30: 413-433.

VITT LJ. 2013. Walking the Natural-History Trail. Herpetologica 69: 105-117.

WELLS KD. 2007. The Ecology and Behavior of Amphibians. Chicago University Press, Chicago, 1148 p.

WIEWANDT TA. 1969. Vocalization, aggressive behavioral, and territoriality in the bullfrog, Rana catesbeiana. Copeia 2: $276-285$.

WiLlis YL, MOYLE PB AND BASKETT TS. 1956. Emergence, breeding, hibernation, movements, and transformation of bullfrog, Rana catesbeiana, in Missouri. Copeia 1956: 30 35.

ZAR JH. 1999. Biostatistical Analysis. New Jersey: Prentice Hall, $663 \mathrm{p}$ 